ARTICLE

Received 30 Mar 2017 | Accepted 5 Jul 2017 | Published 16 Aug 2017

DOI: $10.1057 /$ palcomms.2017.79

\title{
How film genres are a product of biology, evolution and culture-an embodied approach
}

Torben Grodal

\begin{abstract}
The article describes how basic cognitive and emotional systems of the embodied brain are products of a long evolutionary history and how this determines the way in which the major film genres are constructed. It synthesizes research from evolutionary psychology and cognitive film studies, as well as moral psychology. It explains how the film experience is embodied: experienced not only cognitively but with the whole body and its interaction with the world. Also discussed is how the biological underpinning of genres are based on three major types of emotions: a group of reptilian emotions central to action and adventure; a group of mammalian emotions related to offspring of care; and separation panic/ grief. A special human development to enhance group living has expanded emotions of care to also underpin emotions linked to group living such as loyalty to tribe, aggression towards out-groups and submission to tribal hierarchy, central in war, sci-fi and fantasy films, and also emotions related to social rituals such as comedy, tragedy and musical. A discussion is also offered of how the historical development from hunter-gatherers via societies based on agriculture to the present post-agrarian society has moulded moral emotions; this is exemplified in relation to crime films. Finally, also considered is how age and gender influence genre preferences.
\end{abstract}

\footnotetext{
${ }^{1}$ University of Copenhagen, Copenhagen, Denmark Correspondence: (e-mail: grodal@hum.ku.dk)
} 


\section{Genres as prototypical categories}

he word genre is one of the most used words to classify and describe film. It is used as a marketing label, it is used as an analytical tool and it is important concept for understanding the interplay of biological and cultural determinants in creating viewer interest. The origin of the concept genre is derived from oral, written and enacted storytelling and film has borrowed the term for the very good reason that most film has copied central elements of their storytelling from literature and theatre narration.

The causes for the existence of genres have evoked heated debates. Especially prominent for the last 40 years have been a culturalist-ideological take on genre. An important inspiration for this has been French deconstructivism, with Michel Foucault as a key proponent. The main idea is that cultural forms represent deep-rooted unconscious ideological determinants of how our conscious life and mental forms are moulded. From this point of view Hollywood genres are expressions of capitalist ideology. An early example of such a take on genre is Robin Wood's Ideology, Genre, Auteur (1976) that describes how dominant Hollywood film genres are ideological. Numerous film scholars have followed and expanded that approach. I will not dispute that films contains culture-specific values, on the contrary, a biocultural approach as I have laid forward in Grodal (2009) argue for the importance of culture. However, culture is only possible on top of the biological affordances and constraints of our embodied brains as I will argue in this article. An extreme culturalism presupposes an embodied brain that is totally malleable, a sheer computer programmed by ideology and disregard the broad spectrum of emotions and understandings that are based on our shared embodied human nature.

Another take on genre theory that I may call professional engineering, expressed for instance by Bordwell (1986), Altman (1999) and also by Mittel (2004), is to look at genres from a technical-social point of view: How are genres constituted by the constant interaction of director knowhow, production conditions, viewer skills and marketing conditions, including shifting viewer interests. This is a valid and interesting procedure but it does not explain why certain forms and certain narrative contents have dominated for millennia and it does not explain the fascinations that mould the dominant narrative forms. The film media has been a key media for articulating basic human perceptions, emotions, cognitions and actions, and without understanding the substance of film, the human embodied nature, film studies become a rather narrow technical discipline. Malcolm Turvey (2014) has articulated a critique of my biocultural approach to film studies, argued that if I argue that we do not only need neuro-biological and evolutionary explanations to describe film but also a description of those cultural procedures and ideas that make a given film successful (or unsuccessful) then my arguments for an evolutionary and neurological approach to film studies have problems, despite that my arguments for bioculturalism argues for exactly the same position as Turvey except that I point out how central aspects of film needs an neuro-evolutionary explanation. We need the understanding of the embodied nature of the film experience as well as an understanding of the cultural specificities and the aesthetic knowhow and cultural setting of the given filmmaker. So let me turn to the embodied support of genre formation.

Narrative genres have developed and mutated for many thousand years and many narrative elements have been around since the beginning of storytelling. The first story known is the Gilgamesh epic written in cuneiform letters and it is probably close to 5000 years old. It has many of the elements that also nowadays are elements in genres like adventure, fantasy, historical films and love stories, just as the younger Greek epic stories The Iliad and Ulysses has core story elements that are still used as skeletons for present day movies. This indicates that even if genres are influenced by cultural elements there must be strong influences from innate dispositions.

A given narrative film consists of numerous elements, such as different actions (running, fighting, sleeping, making tools), different emotions like love, fear, hate and disgust, and a series of scenes that focuses on social interaction. It may portray different social groups from kings to ordinary people, and different age groups and genders. A given film consists of a specific selection of some of these elements of actions, emotions and of social and gendered prototypes. A genre consists of a group of films that have a prevalence of some of the elements of the total sum of elements in human existence, including elements in their environment. Say a film is labelled a crime film it will certainly have crime and detection, scrutiny of the environment for clues, but maybe also travelling or fighting; a romantic film may certainly have love as a dominant element but may also have elements of war as in Gone With the Wind. Some of the main genres are characterized by one or two dominant emotions, like love, fear, laughter or angry aggression.

A genre is not an Aristotelian category with a certain amount of necessary and sufficient elements. A given genre is a prototype category as described by Eleanor Rosch ( $c f$. Lakoff, 1987). This means that some members of a given genre are more central for the category, that is, possess more of those elements that are typical for a given genre, and others are less typical. Central for the genre crime fiction for example is the portrayal of a detective that does detection and often investigates a murder, and films that accord with this will accord with the central prototypes. However, crime fiction may also use detection to find out about theft and it may or may not add a romance and if romance elements increase the film will be less prototypical. You may have films on the borderline between different categories say a film that is fully a mix of a romance and an adventure. Further, most genres exist in a pure form and a comic form as romantic comedy or horror comedy. Genres may change over time by adding or omitting elements. Some elements have been dominant as long as story telling has existed, others are adaptations to changing social and cultural conditions.

\section{Selection of narrative patterns/genre patterns by optima}

A traditional understanding of genre consist in thinking that somehow some cultural norms for genres has been invented and that these norms are repeated over and over again. The tradition thus emphasizes conventions that may sometimes be perceived as arbitrary. However, Richard Dawkins (1976) has in his book The Selfish Gene proposed at theory that he calls meme theory claiming that just as biological beings survive by and compete by means of genes that are reproduced so cultural ideas and products, called memes by Dawkins, may be described in a similar fashion ( $c f$. also Sperber, 1996; Blackmore, 1999). A given idea or cultural pattern, a meme survive by being reproduced. In analogy to this a functional approach to genre emphasizes that the genres develops by the same mechanisms as other types of evolutionary selection. Just as a given animal or human compete with other animals or humans for survival of its genes, so also a given narrative pattern, a given story skeleton, or a generic pattern, competes for survival in a struggle with other stories and story elements. Whereas humans and animals competes by having offspring that is better suited for survival than the offspring of other animals in a given niche thus also stories competes for survival. The measure of fitness is the ability of a given story to be retold, or seen as film over and over again. Successful narratives 
trigger central emotions and central action patterns, and some narrative may adapt to a local social world or major social changes. Thus, a story's fitness expresses its ability to find a niche in the social world in which the given story is retold. This survival may-in contrast to animal and human survival by procreationtake place in full: The Odyssey story may still be made into a film, be reprinted and so on. But the more typical way of survival is by having the given story's "DNA", its central generic patterns be remade with a new narrative surface-new names, locations and so on-but with the fundamental narrative patterns intact. Often originality is described as a key element in the success of a given film; however, the originality is mostly a new surface for a successful story DNA.

Central for this survival by reproduction and innovation of the basic narrative features with minor surface variations takes place by a continuous interaction between storytellers and audiences or film producers and box office. Animals and humans develop and adapts to new environment by mutations, most of which are maladaptive, but a few mutations enhances adaptation ( $c f$. Altman, 1999). Likewise, filmmakers may make mistakes by making changes that do not get viewer approval but also produce fitness-enhancing modifications, whether these optimize general elements (say, inventing new ways of creating suspense or to enhance visual salience) or whether they make adaptations to cultural changes in viewer life circumstances, social segments and/or preferences.

In narrative production and especially in film production the process of enhancing fitness take place by a deliberate combination of reproduction and innovation that continuously get feedback from the box office. However, in the case of some art films it is not box office success in general but their success among distinguished critics that may represent a niche parameter of success. To understand what parameters are essential for the production and reproduction of generic patterns we must look into the biological underpinnings of human nature that is essential for creating the foundation for narratives and genres.

\section{Storytelling, embodiment and evolution}

Storytelling is probably as old as human language. As described in Brian Boyd (2009): On the Origin of Stories sharing of information between early humans has been vital for human survival. The invention of language provided quite new possibilities for sharing information vital for survival. It might be a storyteller describing how to find fruits and avoid dangerous animals. It may also, as pointed out by Robin Dunbar (1996): Grooming, Gossip and the Invention of Language be gossip and social information for instance about stealing, cheating and secret sexual relations. As pointed out by Boyd and Richerson (1998), Richerson and Boyd (2005) and Tomasello (2009), humans are extremely social animals and their evolutionary success has been based on information sharing. Stories, narratives, have been the perfect tool for such an information sharing.

But how did language and storytelling evolve? The traditional theories of language have been based on the idea that language was an abstract "disembodied" system similar to that of computer language. Central theories in the humanities have been influenced by two related paradigms: the semiotic-linguistic paradigm and the culturalist paradigm. The central idea in classical Saussurean linguistics is that language consists of an arbitrary system of differences-the sounds/letters and their combinations into words. These arbitrary signifiers are then linked to some signifieds, the sounds cow is for instance linked to an animal. The signifier-part of language is arbitrary with no natural link to the signified. This arbitrariness of the signifiers also became a model for the content side of language that was supposed to be cut up in arbitrary ways, eventually by cultural idiosyncrasies. The way the world was represented in language and narrative was fully culturally determined.

However, for the last three decades the idea of the culturally determined arbitrariness of the content side of language has been strongly modified and replaced by an understanding of how the semantic part of language has evolved out of the human embodiedness. The idea of embodiment has been on the rise as a foundation for describing central issues in a series of scientific disciplines, such as evolutionary theory, psychology, linguistics, literary theory and film theory (cf. Johnson, 1987; Lakoff, 1987; Carroll, 2004; Tooby and Cosmides, 2005; Boyd, 2009, Grodal, 2009). The central concept in embodied theories is that the human mind/brain is embedded in the body. And further, that the body/ mind has evolved in interaction with the life-world of the living beings to solve vital survival problems. Thus, to describe the functioning of the mind and its processing of input and output you need to understand how the brain has evolved in the flesh, how we think with eyes, guts and muscles so to speak.

In 1991 Varela, Thompson and Rosch published the manifesto book The Embodied Mind. The central idea is that: "By using the term embodied we mean to highlight two points: first that cognition depends upon the kinds of experience that come from having a body with various sensorimotor capacities, and second, that these individual sensorimotor capacities are themselves embedded in a more encompassing biological, psychological and cultural context." Rosch et al. (1991), pp. 172-173. The book conceived embodiment theories as an offspring of MerleauPonty's phenomenology-for example, his most important work Phenomenology of Perception 1945, eng. Translation (1962). Another central book in the theory of embodiedness is George Lakoff's Women, Fire and Dangerous Things. Here, he describes how language by means of metaphor is strongly based on embodiment. Although there is no reference to Merleau-Ponty, Lakoff's book is also inspired by phenomenology (personal communication). The central idea is that even abstract thought is based on metaphors derived from our basic experience of our bodies and their relations to our life-world as described by phenomenology. A metaphor like "the path to success" uses the basic experience of moving along a trajectory to describe a transition from non-success to success. Stimulating input may be called food for thought and you may balance a budget by projecting from a body experience to bookkeeping.

A related embodied approach was made by Gibson (1979) for example, in his book The Ecological Approach to Visual Perception. His main idea is that our perception is intimately related to our muscular action potentials. When walking in a wood and seeing a trunk lying on the ground we experience the trunk as "sit-able". When children see a small puddle they see it as stump-able and a chair may be push-able. Thus, our perception is intimately integrated with our muscles and our action potentials. To exemplify it on film: When McClane in Die Hard is fleeing through the Nakatomi building his and our perceptions are geared at structuring the environment from the perspective of possible actions: Here is an air channel that is "crawl-able" and thus an escape route, there is a table right here, it is "hide-able" if there are villains that are approaching McClane; but in other contexts the table might be perceived as "affording eating" ( $c f$. Grodal, forthcoming). A given container in space (a cave, a part of a building or car) may afford secret observation, but secret observation may also take place by means of cameras or binoculars. In other situations containers are "protect-able" and our perception of space and spatial features thus depends on action intentions.

Central for a series of film genres such as action, adventure or crime fiction is such a steady playing through of the interaction 
between an agent's perceptions and the affordability of basic actions in relation to the environment and to other agents. Grodal (2011,forthcoming) has described some basic scenarios that I have called HTTOFF-scenarios, short of Hiding, Tracking, to Trapp, being Trapped, Observing, Fighting and Fleeing. Such scenarios are the basis for all action-oriented genres and represent modes of relating to other agents and the world based on fundamental affordances that humans share with all other animals. McClane in Die Hard hides, observes, flees and fights and is trapped in an urban landscape just as agents in many crime fictions or action movies. Action films like the Bourne trilogy or the Die Hard pentalogy may by attention catching due to the constant flow of perceptions, emotions, cognitions and actions that activate this fundamental living through of the interrelation between the affordability of the physical world and the agencycapabilities of humans (or even of animals as we see it in many animated films in which it is animals that live through HTTOFF scenarios.

The brain mechanisms by which we enjoy such an embodied interaction with the world is inherited from our animal and hunter-gatherer-ancestors and this explains the strong fascination with such types of narrative even if most people in the modern world seldom has an existential need for HTTOFF-scenarios. The daily life of animals may also be a mise-en-scene of such scenarios that represent fundamental ways of interacting with other agents in the physical world and mammals are provided with the ability to play. What animal or human children are playing is very often based on HTTOFF scenarios in the form of playing hide and seek and play-fight and play-pursuit.

The link between perception and action as expressed in the term affordance points to the fact that our experiences-whether cued by words or images-are holistic-vision cannot be severed from action and both processes cannot be isolated from the body and its reaction cued by actual or virtual interaction with the world. Further, all film experiences constantly cue fluctuations in the body's level of arousal that is related to the body's oscillations between coping and relaxation. So, even when watching films the whole body from top to toe will-cued by the given narrative situations-fluctuate in blood pressure, sweat and muscular tension. Film viewing is embodied and based on a steady flow from perception, to activating emotions to cognition and finally motor action that allows for a new flow. This is the so-called PECMA flow (abbreviation of Perception, Emotion, Cognition and Motor Action, cf. Grodal, 2009).

\section{Embodied brain, emotions and the PECMA flow}

Central for understanding human embodiedness and the viewers' preferences for genre film is insight into the way in which the human brain has evolved to solve survival problems. The human brain is the result of hundreds of millions of years of evolution. If you look into the human brain the oldest part down at the top of the brainstem is inherited from reptiles. The neurologist Jaak Panksepp has (in 1998 and 2012) described four basic emotional systems that we share with reptiles, birds and other mammals: Anger, Fear, Sexual Lust and Seeking. Anger, fear and sometimes also lust are central to all action-oriented genres. Seeking demands an explanation: Seeking is the dopamine-supported emotion that motivates the seeking up of resources, like food, shelter and so on but may also serve as an aid for other emotions. Seeking steer attention and action: When hungry you spot the environment for traces of food, when in sexual lust you check the environment for clues for a mating partner, and when afraid you check the environment for clues to an existence of possible dangerous others in the neighbourhood. Seeking is the dominant emotion in many types of crime fiction and mysteries: The world before your eyes and ears are not interesting in themselves, only if you may find clues and traces that points to something else, the whereabouts of the criminal, for instance.

Thus again, perception, vision is intimately linked by and influenced by emotions and affordances for motor action. It is easy to see that crime fiction and mysteries in some aspects inherit central skills necessary for our hunter-gatherer ancestors to seek up resources and avoid predators, even if-as I will explain later-the seeking is also motivated by higher-order moral emotions, because, contrary to the seeking performed by the typical hero in action or adventure film that is motivated by personal interest (McClane for instance wants to protect his wife), the detective is often an outsider that without personal benefit helps the community. Likewise war heroes may be motivated by moral emotions linked to their tribal identity.

On top of the reptilian brain we find according to Panksepp (1998),Panksepp and Biven (2012) and others elements that are an add-on in mammals and to some degree birds: care, panic/ grief and playing. In contrast to reptiles, mammals care for their offspring, thus humans take care of their children for many years and infants are unable to survive without parental care. Care is, therefore, an extremely strong emotion (supported by the neurotransmitters oxytocin and vasopressin), and it works in tandem with panic/grief, the emotion elicited by separation of care-person and care-object. Thus, the driving force in most films for children is panic by separation (for example, Finding Nemo, Spirited Away, Totoro, Bambi), but also action and adventure film may have care and panic as their supportive emotion (McClane's fighting is motivated by panic and care).

Due to the enormous cost of raising children that only are fully self-supportive in their teens, a series of researchers (for example, Fisher (2004) have proposed that a biological underpinning for pair-bonding has evolved so that humans typically live in pairbonds (supported by bonds forged by oxytocin-vasopressin so that men may share some of the costs of raising children, just as birds mostly form pair-bonds for the same reason, in contrast to most other mammals for whom the cost of raising offspring is the sole responsibility of the females. This need for pair bonds have been the foundation of one of the oldest and most important narrative genres, the romantic narrative and we find romantic narrative elements from Gilgamesh to Pride and Prejudice or Pretty Woman (cf. also Kramer and Grodal, 2012). Clearly, pair bonds have traditionally been more important for women than men, because in principle men may abandon the mothers and not pay the price it costs to raise a child. It has been argued by Munck et al. (2016) and others that the "hunter-gatherer" disposition for romantic love to various degrees have been suppressed in societies based on extended families typical of some agrarian societies because here it is the family that is responsible for taking care of offspring, and thus such societies like arranged marriages that guarantee that husbands are qualified as providers. Stories conflict between families and individuals in love is not that prominent in modern love stories except in historical contexts like in film versions of Romeo and Juliet.

Sexual lust in total disjunction of romantic love is prevalent in porn films that predominantly have a male audience. Not surprisingly, audience research (cf. Bennett et al., 2009) show a massive dominance of female viewers to romantic films as a consequence of bio-psychological determinations even if the cultural and economic development have made the need for male resources for bringing up baby less important.

\section{Sadness, humour and film as social rituals}

The positive emotion Care has a cost: The panic is induced by separation from a loved one and if the separation become 
permanent it result in the emotionally negative emotion Grief. Most films for children have panic as a central emotion and driver of narratives that are often-as in Finding Nemo-of the adventure form: finding the lost child or parent through a search through a physical space. Grief by the permanent separation caused by death is historically one of the most important genres, called by different names such as tragedy and sad melodrama.

But why should stories that focuses on pain be retold and reinvented century after century? A central explanation for this is that storytelling, whether in theatres, cinemas or on print is part of a social ritual in which audiences share experiences and thereby may not only boost joy as in happy musicals, but also alleviate pain by sharing the experience in a ritualistic fashion. Film historically emerged as a social event, with theatre as the nearest relative to film so that cinemas are even today called theatres. In theatres and cinemas social groups share a focus of attention and explicitly or implicitly feel that their experience is a "group experience". The film experience centrally contains elements of being social rituals in the sense expressed by Emile Durkheim (1915) as being means to provide group cohesion and also to deal with existential problems. This is obvious in the role of ritual in central rites of passage like birth, marriage and death. Durkheim's theoretical approach to ritual has been expanded within microsociology, for instance by Goffman's frame analysis (Goffman, 1974) and Randall Collins' interaction ritual chains. Collins has (in 2004: 7) defined ritual as follows: "ritual is a mechanism of mutually focused emotion and attention producing a momentarily shared reality, which thereby generates solidarity and symbols of group membership". To be member of an audience is to share a common focus and share a series of emotions and the explicit or tacit feeling of group belonging need not be physical, it is often only imagined as when viewing films alone. When watching films-even alone and from a DVD or streamed-viewers are tacitly or explicitly aware of the fact that they are viewing sounds and images that are intended to be viewed by many, meant for a public display.

Just as sad stories have perennial appeal because they allow people to share existential emotions also comic stories are intimately related to ritualism. Comedies rely on the third major mammalian emotional system, playing. Playing allows for performing all kinds of actions in a fictitious, "non-real" mode (cf. Grodal, 2014). Central forms of playing in mammals are hide and seek, catch me if you can, and rough and tumble fighting. When playing or showing or telling humorous events such events are as such arousing, producing adrenaline and need for some actions to alleviate the arousal-say to escape from the person that is trying to catch you. But in a playful mode part of the arousal is transformed not into world-modification (for example, the fear linked to being pursued in a catch me situation that should motivate escape) but to self-modification: when playing "catch me if you can" the person caught will laugh as much as the one catching. The laughing is part of the self-modification but it is also an important play-signal between the playing persons: this is just fun, we have a play contract. In comic entertainment, it is important to emit play signals to create a ritualistic experience of living through phenomena that we deem "not real", just for fun. Central part of comedies and comic entertainment actually deals with painful or embarrassing phenomena, from losing balance and falling, due to a banana peel to being caught in embarrassing situations. Thus, comedies are mostly a living through of failures and pain, but in a context that says: this is just for fun, enjoy your arousal, and let it get outlet by laughter. That comedies and comic entertainment heavily depend on a social, ritualistic context may be seen from the fact that people are 30 times more prone to laugh when in company with others than when alone (cf. Provine and Fischer, 1989 cf. also Provine, 2000) and also that comic entertainment on TV are often provided with a laugh track that try to compensate for the possible lack of a laughing community when watching TV. Laughter is not only a way of transforming action tendencies in the peripheral body (run away from the one that want to catch you) to self-modifying activity in stomach and lungs, ha, ha, but it is a way of synchronizing the minds and bodies of a social group in a shared laughter. Thus, comedy is a kind of social therapy where all the negative events, from falling or being caught, to social embarrassment and defeat as in a Chaplinesque comedy, may be shared in a profoundly embodied fashion in what you might call a "social body" of viewers that are not only linked by a shared attention on the story but also by the rhythmic embodied laughter.

The Musical genre is strongly related to comic entertainment by the role of ritual and creation of a shared viewer "body". In a musical the narrative and the performance must follow patterns that are not-as in an action or adventure story-meant to express a free and undetermined temporal flow. On the contrary, the set-up is meant to indicate a special reality status similar to those of other social and religious rituals. In musicals actors sing in accordance with supra-individual patterns: the music. The expressions in the songs are often repetitive and viewers are invited to participate in a social ritual by the power of the strongly patterned audiovisual space. In their book on film music Adorno and Eisler (1947) hinted at the role of film music as part of a ritual, and Gorbman (1987) discussed how film music might provide an audience-centered feeling of spectacle. The nonindividualistic nature of musicals may often even be expressed in the narrative itself, as when a musical is focused on portraying a community. In On the Town three sailors pair bond with three girls and on the background of a city, New York as a community. So the experiences of a city community and of individual bonds are framed as a happy musical ritual of group bonding. Other musicals-like West Side Story use the ritualistic framework to provide a framework of sharing sadness. Music is rooted in human rituals aimed at creating tribal bonding, whether linked to sharing happy or sad events and film music in general functions as a means to strengthen the viewers' feeling of participating in a social ritual even when watching "non-ritualistic" genres like action and adventure.

\section{Embodied ultra-sociality and morality}

As discussed by for instance in Boyd and Richerson (1998) and Tomasello (2009), humans are ultra-social and their success depends on group living. Early hunter-gatherer groups were small and relatively non-hierarchal and enjoyed the advantages of information sharing but also the advantages of tribal cohesion. Over time the deadly fights for resources with other tribes became increasingly important. This has lead to a reconfiguration of the emotional systems by expansion of care and panic so that in humans the emotions care and panic may be activated not only in relation to children, but also in relation to the care of the extended family, the local community and tribe and even to super-tribes like nations and kingdoms, due to the survival benefits of cooperation. Societies vastly bigger than the small hunter-gatherer societies were formed by the transition to agrarian societies. From the time of the big empires of Mesopotamia, Persia and Egypt onwards culture and social life became increasingly based on hierarchy and intertribal war.

The link between moral norms linked to tribal living in large groups and its central motivation in tribal conflict is easy to spot even in present day films. In war films such as Saving Private Ryan or buddy films such as Lethal Weapons individuals risks or even sacrifices their lives for the benefit of their comrade in arms or their nation. The moral emotions that back up such unselfish 
behaviour that do not provide any proximal fitness for the individual that sacrifices him/herself is an indication of the enormous benefits of cooperation that it has been ingrained in the human DNA in the form of morally induced emotion of care and submission to common goals.

It is important to emphasize that moral emotions does not make up one unified and unambiguous batch of moral attitudes but are heterogeneous as discussed especially by the moral philosopher Haidt (2012). Some moral dispositions are inherited from our hunter-gatherer ancestors that had rather egalitarian societies with strong opposition to bullying. Other dispositions are remnants from our ape ancestors that mostly were very hierarchal, with the strong exerting dominance and the weak showing submission. The dominance/submission emotions are also central in the relation between adults and children ( $c f$. the way in which a god/human-relation is often described as a fatherchild relation). The emotions and action tendencies linked to hierarchal social relations have as mentioned been reactivated in the last 10,000 years because when agriculture became the dominant life form of humans, societies became increasingly unequal and based on hierarchy as we especially know from films from the middle ages with slaves at the bottom and kings and emperors on top. Stories like Robin Hood tries to make a mix of "hunter-gatherer" egalitarianism (the robbers in Sherwood Forest) and a feudal hierarchal relations of knighthood and servitude (for example, to King Richard the Lionheart) and the constant popularity of such medieval stories may express that it is more easy to live out such stories of social inequality-based on innate dispositions for domination and submission-in premodern environments.

Jonathan Haidt has argued that there are six moral dimensions that are often in conflict with each other, partly because they have roots in different phases of human evolution so that different present day environments may (re)activate different inherited dispositions. The first two moral dimensions are: 1. Care vs. Harm, care is good, harm is bad, a core mammalian emotion. 2. Fairness vs. cheating, necessary for resource sharing that necessitate that you punish cheaters and free-riders. Those two moral norms are linked to rather egalitarian societies and in modern days linked to liberal values. The next dimensions are more conservative and closely linked to possibly unequal and hierarchal societies: 3 . Loyalty-betrayal, based on the demands of forming coalitions/tribes of a certain size. 4. Authority/subversion dimension based on cooperation based on hierarchies. 5. Sanctity/ subversion dimension, originated in advantages of cleanliness and protection against bad food, but developed to be a means of stating absolute values (for example, as if in-groups are perceived to be good because they obey certain rules of sacredness and profaneness, out-groups are bad and unclean). The last dimension is: 6. The Liberty-Oppression dimension that is developed to prevent bullying and authority and in this respect it is in conflict with 3-5, but it might also express an individualism that sometimes is in conflict with 1 and 2, sometimes with 3-5 (cf. American libertarianism).

The heterogeneity of the moral systems and their relations to different layers of the human evolutionary history and different layers of the present day societies enable various types of films to activate different and often conflicting emotions. As mentioned, traditional war films such as Saving Private Ryan fully support a type three and four morality with a submission to hierarchy, authority and tribal sanctity. However, the HBO series Game of Thrones shows a world in which the moral principles of loyalty are in conflict with authority and also with care and fairness. Many action films such as Die Hard demonstrate conflicts between care and (a problematic) authority, just as many films deal with the problems of corrupt authority, like L.A.
Confidential. Such films, and also many westerns might, besides care and fairness, also advocate a wish for moral principle number 6., liberty, and numerous films since the sixties, from Bullitt and Dirty Harry onwards have had such "libertarian" themes, whether given a right-wing or a left-wing tone.

\section{Genre, innate dispositions and social transformation}

Even if storytelling is based on innate dispositions that have not changed in modern times, nevertheless changing social conditions may select new configurations of the innate dispositions in combination with new social environments. I will exemplify this by the rise of crime fiction during the nineteenth and twentieth centuries. Although crime fiction is a relatively new invention compared with action-adventure, comedy or tragedy it is based on a set of very old mental dispositions. It is first and foremost based on the dopamine-based disposition for seeking: The scrutiny of the environment for clues to finding something wanted, food, mate or whatever that is not accessible in the immediate visible environment. Seeking by means of clues and cognition is, therefore, a central activity for hunter-gatherers as well as all other types of human and animal existence. When the cities grew large in the nineteenth century and perceived as mysterious jungles, French and British writers created a new genre, crime fiction, inspired-as exemplified for instance in Dumas' novel The Mohicans of Paris and the work of Conan Doyle-by a blend of the methods of science and the behaviour of hunter-gatherers like the native Americans. Crime fiction is at the same time based on an effort to perform psychological analysis of people to reveal their hidden motives and behaviours, and, as pointed out by Dunbar (1996), the gossip-based interest for other people in hunter-gatherer tribes is a central factor in the development of human social intelligence and might be a central factor in the development of human culture.

However, pre-modern societies were, with some exceptions, based on small rural communities and even if such societies also had problems with secret murders and thefts the small communities, the central problems caused by armed conflict and social inequality were out in the open and dealt with in action-based narratives. This changed by the rise of big cities in the $19^{\text {th }}$ century and the modern creation of crime fiction was centred in Paris and London that also were centres for the creation of modern police and police techniques to reveal the secrets of the opaque modern mega-societies. Crime fiction has become a major genre in the twentieth and twenty-first centuries, selected for by the emotion seeking and the moral emotion-configurations that Haidt has called care and fairness, with those social-psychological disposition for the surveillance of other people that Dunbar (1996) has linked to gossip. Crime fiction has become a major genre for social and psychological "tourism" into' the various environments of modern complex societies. To various degrees crime fiction may incorporate elements of action, violent confrontations and use of HTTOFFscenarios.

Crime fiction has further become a central vehicle for articulating Haidt's fifth moral dimension, the sanctitysubversion dimension. An important subgenre within crime fiction describes psychopaths and the perverted that transgress the sanctity of the body as in Se7en, although the central genre for articulating the violation of sanctity, mostly of the body, is horror films like The Exorcist.

\section{In conclusion: Major film genres and their audiences}

As discussed earlier genre categorization is not a very precise discipline, a generic label just provides a rough indication of their content and narrative form. The following list may give an 
impression of the labels that typically are provided on genres: Action, adventure, romance, comedy, tragedy, science fiction, horror, animated films, thriller, drama, fantasy, historical films and musicals. One group, action and adventure, is based on basic mammalian behaviours, fighting, bonding and moving through space for resources; a central group of genres is based on their ability to cue basic emotions: Romance, Comedy, Tragedy/sad melodrama, thrillers and horror films. Drama is a very broad category that may include most aspects of human life. A last group is further based on an alternative reality status: Animated film, Science Fiction, Fantasy and Historical Drama. In several dimensions such films share their basic narrative set-up with action, adventure and romance, but provides a freedom for providing alternative environments and also alternative agency functions (Animated films allows for having talking animals, plants and even artefacts like toys. Science Fiction and Fantasy are mostly based on action-adventure schemata such as HTTOFFscenarios but are special for having fantasy agents like robots and strange monsters and colourful settings in space or fantasy worlds with alternative physical laws.

Not surprisingly the factors that most determine the relation between genres and viewer preferences are based on biology, namely age and gender, two important biological determinants. Empirical studies ( $c f$. for example, Bennett et al., 2009 and Wühr et al., 2017) show that film preferences are strongly linked to gender and the empirical studies confirm stereotypes. Age especially determines genre preferences in two dimensions, the degree of fantasy vs. realism and the dimension of the degree of arousal cued by the genre. Films for children are predominantly animated films that combine basic narratives with prominence of care/panic and adventure-narrative with fantasyagents and fantasy settings. Although all age groups except small children may watch Science Fiction and Fantasy, the central viewer group is young people between 15 and 30 (although there is a fluid transition from animated films for children and fantasy and SF). Old people like realism better than fantasy. Not surprisingly the preference for high arousal films such as horror films and extreme thrillers is highest from the onset of puberty until the beginning of the $30 \mathrm{~s}$. Gender is the strongest determinant of genre preferences that unsurprisingly follows gender stereotypes: Women prefer romantic films and films that rely on social intelligence, such as crime fiction and costume drama, more than men, and men prefer films that depict violence such as war films, science fiction and Westerns much more than women. The common denominator between men and women are according to the British Film Institute study (Bennett et al., 2009) comedy, cartoon and also action/thrillers and also men have a liking for crime fiction, although to a lesser degree. It is interesting that the big difference in the interest of horror and fantasy is not related so much to gender but-as mentioned-to age. The genres are prototype labels and, therefore, filmmakers may make all kinds of crossover products, especially to bridge the gender differences in preferences as when adventure is mixed with romance.

Genres are thus embodied in many dimension, they represent cultural constructions to adapt to the preferences of our embodied brain and its emotions and action potentials in relation to the world and the preferences are partly linked to biological age and gender.

\section{References}

Adorno T and Eisler H (1947) Composing for the Films. Oxford University Press: London, (NB Adorno was not listed as an author in the first edition).

Altman R (1999) Film/Genre. BFI: LondonBFI.

Bennett T, Savage M, Silva E, Warde A, Gayo-Cal M and Wright D (2009) Culture, Class, Distinction. Routledge: London \& New York, NY.
Blackmore S (1999) The Meme Machine. Oxford University Press: Oxford. Bordwell D (1986) Narration in the Fiction Film. Methuen: London.

Boyd B (2009) On the Origin of Stories. Evolution, Cognition, and Fiction. Harvard University Press: Cambridge, MA.

Boyd R and Richerson P (1998) The evolution of human ultrasociality. In: EiblEibesfeldt I and Salter FK (eds). Indoctrinability, Ideology and Warfare. Berghahn Books: New York, NY, pp 71-93.

Carroll J (2004) Literary Darwinism: Evolution, Human Nature, and Literature. Routledge: New York, NY.

Collins R (2004) Interaction Ritual Chains. Princeton University Press: Princeton, NJ.

Dawkins R (1976) The Selfish Gene. Oxford University Press: Oxford.

Dunbar R (1996) Grooming, Gossip, and the Evolution of Language. Faber: London.

Durkheim E (1915) The Elementary forms of religious life. Georges Allen and Unwin: London.

Fisher H (2004) Why We Love: The Nature and Chemistry of Romantic Love. Henry Holt: New York, NY.

Gibson JJ (1979) The Ecological Approach to Visual Perception. Erlbaum: Hillsdale, NJ.

Goffman E (1974) Frame Analysis: An Essay on the Organization of Experience. Harvard University Press: Cambridge, MA.

Gorbman C (1987) Unheard Melodies. Narrative Film Music. BFI: London.

Grodal T (2009) Embodied Visions. Oxford University Press: New York, NY.

Grodal T (2011) Crime fiction and moral emotions: How context lures the moral attitudes of viewers and readers. Northern Lights; 9, 143-157.

Grodal T (2014) A general theory of comic entertainment: Arousal, appraisal, and the PECMA flow. In: Nannicelli T and Taberham P (eds). Cognitive Media Theory. Routledge: New York, NY, pp 177-195.

Grodal T (forthcoming) A close reading of Die Hard as an emotion symphonyHow reptilian scenarios meet mammalian emotions in the flow of an action film. Projections; 11 (2).

Haidt J (2012) The Righteous Mind. Why Good People are Divided by Politics and Religion. Pantheon: New York, NY.

Johnson M (1987) The Body in the Mind: The Bodily Basis of Meaning, Imagination and Reason. University of Chicago Press: Chicago, IL.

Merleau-Ponty M (1962) Phenomenology of Perception. Trans. Colin Smith Routledge and Kegan Paul: London.

Kramer MGrodal T Partner Selection and Hollywood Films. (2012) The psychology of love. In: Paludi MA (ed). Emotion and Romance. Santa Barbara: Praeger, Vol. 2, pp 3-22.

Lakoff G (1987) Women, Fire, and Dangerous Things. What Categories Reveal about the Mind. Chicago University Press: Chicago, IL.

Mittell J (2004) Genre and Television: From Cop Shows to Cartoons in American Culture. Routledge.

Munck Vde, Korotayev A and McGreevey J (2016) Romantic love and family organization: A case for romantic love as a biosocial universal. Evolutionary Psychology October-December; 2016, 1-13.

Panksepp J (1998) Affective Neuroscience: The Foundations of Human and Animal Emotions. Oxford University Press: New York, NY.

Panksepp J and Biven L (2012) The Archaeology of Mind: Neuroevolutionary Origins of Human Emotions. Norton: New York, NY.

Provine R and Fischer KR (1989) 'Laughing, smiling and talking: Relation to sleeping and social context in humans. Ethology; 83 (4)1989 295-305.

Provine R (2000) Laughter. A scientific investigation. Penguin: New York, NY.

Richerson P and Boyd R (2005) Not by Genes Alone: How Culture Transformed Human Evolution. University of Chicago Press: Chicago, IL.

Rosch E, Thompson E and Varela FJ (1991) The Embodied Mind: Cognitive Science and Human Experience. The MIT press: Cambridge, MA.

Sperber D (1996) Explaining Culture: A Naturalistic Approach. Blackwell: Oxford. Tomasello M (2009) Why We Cooperate. Boston Review/MIT press: Cambridge, MA.

Tooby J and Cosmides L (2005) Conceptual foundations of evolutionary psychology. In: Buss DM (ed). Handbook of Evolutionary Psychology. John Wiley: Hoboken, pp 5-67.

Wood R (1976) 'Ideology, Genre, Auteur'. Reprinted in "Shadow of a Doubt,"Hitchcock's Films Revisited Columbia University Press: New York, 1989, pp. 288-302.

Wühr P, Lange BP and Schwarz S (2017) Tears or fears? Comparing gender stereotypes about movie preferences to actual preferences. Front. Psychol.. 2017 $8,428$.

\section{Data availability}

Data sharing is not applicable to this article as no datasets were generated or analysed.

\section{Additional information}

Competing interests: The author declares that there are no competing interests. 
Reprints and permission information is available at http://www.palgrave-journals.com/ $\mathrm{pal} /$ authors/rights_and_permissions.html

How to cite this article: Grodal T (2017) How film genres are a product of biology, evolution and culture-an embodied approach. Palgrave Communications. 3:17079 doi: 10.1057/palcomms.2017.79.

Publisher's note: Springer Nature remains neutral with regard to jurisdictional claims in published maps and institutional affiliations. (c) (i) This work is licensed under a Creative Commons Attribution 4.0 (c) International License. The images or other third party material in this article are included in the article's Creative Commons license, unless indicated otherwise in the credit line; if the material is not included under the Creative Commons license, users will need to obtain permission from the license holder to reproduce the material. To view a copy of this license, visit http://creativecommons.org/licenses/by/4.0/

(C) The Author(s) 2017 